\title{
Human Resource Development for Agricultural Sector in India
}

\author{
Mr. M. Manikandan ${ }^{1}$, S. Sheik Abdullah ${ }^{2}$ \\ ${ }^{1}$ Assistance Professor Department of PG Research Commerce, Ayya Nadar Janaki Ammal College, Sivakasi, India \\ ${ }^{2}$ UGC-MANF-Ph.D Research Scholar, PG and Research Department of Commerce,A.N.J.A.College, Sivakasi, India
}

\begin{abstract}
The paper describes a system dynamics model developed for dynamic analysis of human resource development for the agricultural sector in different sources of employment, viz., government, private (including corporate), academic, financial institutes, nongovernmental organizations, self employment, and others in India. Besides projecting an overall scenario for continuation of current agricultural education policy and trends, the paper analyses simulated results from the model for the current curriculum with 80:20 proportion of technical to soft skills. The analysis shows that in the coming years the private sector will emerge as a major employer for the graduates of agriculture and allied sciences.
\end{abstract}

Keywords- Human Resource Development, Agricultural, India.

AGRICULTURAL SECTOR

Agricultural growth is critical for sustainable and inclusive economic growth in India, as the vast majority of the population depends on the agricultural sector for their livelihood. Close to 60 percent of India's labor force is employed in agriculture, according to the 2011 census. The majority of landholdings are small. Some 82 percent were classified as small scale in 2006; and farms less than two hectares occupied 40 percent of India's agricultural land (GoI 2011). Since the Green Revolution era, India has achieved impressive growth in agricultural production, boosting national food security and reducing poverty (Fan, Gulati, and Thorat 2008). But the agricultural sector still faces crucial challenges. Growth in agricultural production continues to lag behind the targeted 4 percent, and poverty and malnutrition remain widespread. Key development challenges for the coming decades are meeting the growing and diversifying food demand, especially for livestock and horticultural products, managing natural resources sustainably, and raising the productivity of rain fed agriculture.

\section{INTRODUCTION}

Human resources constitute the most critical inputs relying on the use of science and technology for development. Agriculture being the backbone of Indian economy, the human resource needs to meet various activities related to agricultural development which is critical to attain country's goals towards rural development, employment generation and host of related activities leading to sustainable growth and development. The growth achieved in Indian agricultural sector has been attributed to the consorted efforts of available skilled human resource. But over the years the scenario has changed. The growth in agriculture sector slowed down and the job opportunities declined leading to increased unemployment. Compounding to this problem, the job requirement of other economic sectors of development has also undergone major transformation encouraging stiff competition from graduates of other disciplines. The increasing unemployment led to serious debate to relook at agricultural education. Education system is perceived to be orbiting along a vicious circle of unemployment quality reduction loss of job opportunity. To break this nexus, the complexity of human resource supply and demand process needs to be analyzed in detail to assess the impact of various contributing factors and policy options. The graduates coming out of the agricultural education system in the country constitute the supply where as the demand stems from various employment avenues. Agencies employing trained agriculture human resource are grouped under seven sectors namely Government, Private (including corporate), Academic, Financial, Non-government organizations, Selfemployment and Others (mostly not related to agriculture directly). The demand for trained agricultural human resource in each of these sectors depends on sect oral growth and attrition rate of the existing employed stock.

Human Resource Development in Agriculture Sector The HRDMD determines the human resource needs for The Ministry of Food and Agriculture. This implies that we are responsible for recruiting qualified staff the training and retaining of MOFA staff to develop the necessary capacities to deliver on the objectives of MOFA. Furthermore, HRDMD manages Agricultural Colleges and Farm Institutes under the ambit of MOFA, for pre service training of trainees for the use of the agricultural sector.

Vision \& Mission 
* To have a well developed and motivated Human Resource with strong desire to drive the engine of growth of the agriculture sector.

* To develop and manage qualified Human Resource to promote sustainable agriculture in Ghana.

\section{Functions}

$>$ To initiate and formulate relevant policies and programmes.

$>$ To ensure that MOFA has the required number and quality of manpower to effectively carry out its assigned roles and functions.

$>$ To ensure that staff with requisite background for all types of work in the Ministry is recruited, trained, re-trained, motivated and developed on a continuing basis for the efficient discharge of their duties.

$>$ To advise the Chief Director on policy issues and laws regarding Human Resource Development and Management.

$>$ To give technical backstopping to the regions and districts.

$>$ To coordinate, monitor and evaluate programmes in collaboration with PMCM\&E.

\section{Responsibilities}

$>$ Establish and maintain system and procedures for planning and controlling human resource development for the Ministry.

$>$ Provide guidance in determining training needs of all categories of workers in the ministry and ensuring that appropriate training programs are develop and implemented.

$>$ Co- ordinate and collate training and manpower development budget and when approved, institutes measures to back up its implementation. Periodically review rules, regulations and procedures relating to training.

$>$ Advise on the preparation and application of training criteria, methodologies and techniques.

$>$ Pursue the development and implementation of adequate proficiency programs to improve the competence of staff in the Ministry and establish appropriate and effective linkages with PBCME and the office of the Head of Civil Service (OHCS) for effective human resource planning.

$>$ Institute measure to provide inter linkages between sector plans and those of implementing agencies relating to training and manpower development to ensure the optimum utilization of personnel within the sector.
Formulate measures to cater for the periodic review of the organizational structure including job classifications and descriptions.

$>$ Assist in the determination of appropriate sect oral manpower levels consistently with the overall operational requirement of the sector.

$>$ Ensure that periodic management and organizational reviews as well as job descriptions, scheme of service and career programmes plans are maintained.

$>$ To manage preserves and Vocational Training in Agricultural Institution s by developing skills and capacities for use by the Agricultural sector

Agriculture the Backbone of Indian Economy and Food Security

India is principally an agricultural country. The agriculture sector accounts for about $18.0 \%$ of the GDP and employs $52 \%$ of the total workforce. There is a continuous steady decline in its contribution towards the GDP, and the agriculture sector is loosing its shine and anchor position in Indian economy. The problems with which the Indian agricultural scenario is burdened in present times are many but this in no way undermines the importance of the sector, and the role it can play in the holistic and inclusive growth of the country. Agriculture is fundamental for sustenance of an economy as is food for a human being. It contributes significantly to export earnings and is an important source of raw materials for many industries.

Its revival is being taken on priority, through various interventions at different levels, because of its potential in reducing poverty and food insecurity. The global experience of growth and poverty reduction shows that GDP growth originating in agriculture is at least twice as effective in reducing poverty as GDP growth originating outside agriculture. Agriculture is and will continue to be the engine of the national growth and development.

\section{Achievements}

The agriculture sector has made significant strides in the last six decades and the country has transformed its position from the net importer to surpluses for the export. Yields per unit area of all crops have grown since 1950, due to the special emphasis placed on agriculture in the five-year plans and steady improvements in irrigation, technology, application of modern agricultural practices and provision of agricultural credit and subsidies since Green revolution. The food grain production increased by 4 times, horticultural crops and milk by 6 times, fish by 9 times and eggs by 27 times since 1950-51. The country harvested a record 230 million tonnes of food grains, produced 6.87 million tonnes of fish and more than 100 million tonnes of milk during 2008-09. India ranks 
second worldwide in farm output. The country is the world's largest and the second largest producer of many crops- the largest producer of milk, fresh fruits (47 million tonnes accounting for $10 \%$ of the world fruit production) cashew nuts, coconuts, tea, ginger, turmeric and black pepper; second largest producer of wheat, rice, sugar, cotton, silk, peanuts, vegetables (81 million tonnes) and inland fish and the third largest producer of tobacco. We also have the world's largest share of cattle and buffalo population. It was the result of harnessing science \& technology that has heralded the Green, White, Blue, and Yellow revolutions in the country. The visible indicators are: increase in per capita food and calorie intake, decline in vulnerability of the Indian agricultural sector to the vagaries of the monsoons, control of price fluctuations, and changing profile of agriculture from subsistence to commercialization. The success has been attained due to commitment of researchers \& policy makers and the sustained efforts of the Indian farmers.

\section{Concerns}

Despite its excellent performance, particularly during green revolution era (1965 - 2000), Indian agriculture today is not as productive, competitive, remunerative and sustainable as expected. The biggest stakeholders -the farmers do not want to participate in its growth. A national sample survey, conducted recently, showed that 40 percent of the farmers want to opt out of their current profession (59th Round of NSSO). GDP per agricultural worker is currently around Rs. 2000 per month, which is only about $75 \%$ higher in real terms than in 1950 compared to a four-fold increase in overall real per capita GDP. The majority of farmers are economically worse off than the lowest-paid government employee. The average monthly income per household from cultivation has been reported as Rs.1, 578 for small farmers and Rs.8, 321 for the big farmers as against the minimum salary of Rs.10, 000 a month to the lowest-paid government employee (Business Standard, 2008).

The widening disparity in per capita income between farm and other than farm sector (the average income in the non-farm sector will be nearly five times what it is in agriculture), the very slow rate of growth in agriculture(paltry 1.3 per cent annual growth in agriculture production over the last 6-7 years), the declining profitability (farmers income rose by a merely 0.28 per cent as compared to 4 per cent in other sectors over the last 5-6 years), extremely weak social security arrangements, weakening family and community based mechanism of social protection, lack of employment opportunities, etc are some of the reasons for farmers or their children opting out of the agriculture profession or leading towards suicide. Every year over about 20,000 farmers commit suicide out of despair over falling crops and high debt (India Today, 2007).

The task is becoming tough for the farmers due to: shrinking natural resources- land area, water, energy inputs; smaller landholding size $(70 \%$ below 1 hectare in 2003 compared to $56 \%$ in 1982); degradation of land and soil, increase in "Wasteland"; pollution of water and poor returns. The ratio of agricultural land to agricultural population has shrunk to 0.3 ha per person in India as compared to over 11 ha per person in the developed countries. The resources are therefore getting marginalized and there is tremendous pressure on natural resources with diversion of agricultural land, water and labour towards industrial, urban and non agricultural sectors. "How to produce enough food without depleting natural resources to feed the growing population" is one of the emerging requirements?" The grim situation is reflected in the quote by an eminent agriculture scientist and the Chairman, National Commission on Farmers- Dr. M.S. Swaminathan "The farming sector is fast heading for total collapse if no rapid remedial measures are taken".

\section{Contributing factors}

The contributing factors could be: low productivity- average yield in our country is generally $30 \%$ to $50 \%$ of the highest average yield in the world; declining public investment in agriculture- as a percentage of GDP has dropped from 3 per cent to around $1.7 \%$ per cent in last five years; fragmented land holdings; poorly maintained irrigation systems coupled with inefficient, unsustainable and inequitable allocation of water; large agricultural subsidies are hampering productivity (budgetary subsidies to agriculture have increased from around 3\% of agriculture GDP in 1976-80 to about 7\% in 2001-03 and fertilizer subsidy has crossed Rs.100,000crore), rudimentary market infrastructure and poor access to markets; poor application of technology, good practices and value addition at farm gate; weak HRD base and almost non-existence of good extension services.

\section{Targets}

By 2020, India's population is likely to be around 1.33 billion, and under the scenario of 5 per cent growth rate in GDP, the total domestic food grains demand will be 294 million tones $(\mathrm{mt})$ comprising $122 \mathrm{mt}$ of rice, $103 \mathrm{mt}$ of wheat, $41 \mathrm{mt}$ of coarse grains and $28 \mathrm{mt}$ of pulses. Similarly, during 2020, the demand will be $126-183 \mathrm{mt}$ of milk, 136-181 mt of vegetables, 68-98 mt of fruits, 6.312.1. mt of meat and 9.5-18.3 $\mathrm{mt}$ of fish. To meet the estimated demand, the yield level over the base period yield (1994-95) is required to be enhanced by 136-157 percent. Considering these trends, National Agricultural Policy rightly envisages growth rate in excess of 4 percent 
per annum in agriculture sector, which is higher than even the highest decadal (1979-80/1989-90) growth rate $(3.54 \%)$ achieved so far. These growth targets are to be achieved against the constraints of diminishing land resources( it is estimated that area under wheat and rice cultivation is estimated to come down from 170 million hectares to 100 million hectares by 2020), increasing biotic and abiotic stresses, indications of decline in factor productivity, threatened loss of biodiversity, natural resource shrinkage and degradation, climate change, tightening of IPR, intensifying competition (quality and cost) in International trade, widening economic inequity besides burgeoning population.

\section{Emerging Areas for Skill Development}

The new emerging areas in agriculture include: green food production, hi-tech floriculture, precision farming, protected cultivation, farming system approach, micropropagation, integrated natural resource management, gene management, integrated pest \& nutrients management, production of quality seeds and formation of national seed grid, watershed management, post harvest management \& value addition, application ofbiotechnology, information and communication technologies, geographic information system(GIS) mapping, space technologies, and conservation of biodiversity of plants, animals, fish and microbes. The major potential of large new job opportunities shall be in the activities related to diversification from cereals to oilseeds and pulses, watershed development for rain fed areas, horticulture, forestry, development of medicinal plants, animal husbandry, social forestry, processing of agro-forest produce, food processing, fishing, and energy plantations. The second green revolution is indeed graduating from grain production to food processing and marketing, and development of vocational \& entrepreneurial skills among the farmers and rural youth. The growth target and priorities call for the development of agricultural human resources as an instrument of national transformation.

\section{SKILL DEVELOPMENT IN THE AREA OF AGRICULTURE}

\section{Weak Agricultural HRD Base}

The concept of HRD in agriculture sector remained a far cry for a considerable period, compared with industrial and service sector. Its weak human capital base and lopsided growth corroborates it i.e. - education is least among agricultural laborers half of those engaged in agriculture are illiterate proportion of educated workers (secondary and higher levels) in profession is quite low (just 5\% have completed Higher Secondary); only 5-6\% of the total graduates are catering to the agriculture system and ratio of Para-professionals to professionals is quite low. The system does not exists for preparing middle level human resource i.e. technicians/ supervisors/ entrepreneurs. Even families operating farms now suffer from much smaller holdings and farming members in such families are twice as likely to be illiterate as nonfarming members. Ensuring food security and farmer welfare thus require support systems to extend technology and scale benefits in a sustainable manner to a huge existing workforce in agriculture that lacks non-farm skills.

\section{Non - Formal System}

Under the non-formal system, the various Departments/ Ministries have established the training centres such as Krishi Vigyan Kendras (569 KVKs) and Jan Shiksha Sansthan (earlier known as Shramik Vidyapeeths under the National Literacy Mission are offering around 225 vocational courses, and provide support to NGOs for running vocational training programmes), Khadi and Village Industry Centres ( KVIC), community polytechnics, state institutes of rural development, extension training centres, etc. The schemes associated are: Agricultural Technology Management Agency (ATMA), TRYSEM and PMRY. The outcome of these training programmes is a mixed lot i.e. we have success stories and cases with the marginal impact. There is a paucity of literature and research on effectiveness and critical condition for the success. The operational limitations under the non-formal system are: (i) lack of recognition, (ii) programmes are not standardized, (iii) lack of comprehensive and continuous evaluation of learners, (iii) inadequate supply of teaching-learning materials, (iv) inadequate supervision and monitoring, (v) lack of regular orientation and training for instructors and supervisions and (vi) inadequate linkage with different organizations and schemes. As a result, the potential of non-formal system is not being realized fully.

Skill Development Based on Modular Employable Skills (MES)

Very few opportunities for skill development are available for the out of school youth and existing workers, especially in the informal sector. Most of the existing skill development programmes are long term in nature. Considering their educational, social and economical background, it was concluded that the poor and less educated persons cannot afford long term training programmes due to higher entry qualifications and opportunity cost. Consequently, a new framework for Skill Development for the informal sector has been evolved by the DGET (Directorate General of Employment and Training - Ministry of Labour and Employment) under the Skill Development Mission to address the above mentioned problems. Modular Employable Skilled (MES) development programme aims 
to equip people with marketable skills. MES would benefit different target groups like workers seeking certification of their skills acquired informally; workers and ITI graduates seeking skill up gradation, early school drop-outs and the unemployed.

\section{Investments in Agriculture}

The agriculture sector has been starved of capital. There has been a decline in the public sector investment in the agriculture sector. Public investment for narrowing regional imbalances, accelerating development of supportive infrastructure for agriculture and rural development particularly rural connectivity will be stepped up. A time-bound strategy for rationalization and transparent pricing of inputs will be formulated to encourage judicious input use and to generate resources for agriculture. Input subsidy reforms will be pursued as a combination of price and institutional reforms to cut down costs of these inputs for agriculture. Resource allocation regime will be reviewed with a view to rechannelizing the available resources from support measures towards assets formation in rural sector.

A conducive climate will be created through a favorable price and trade regime to promote farmers' own investments as also investments by industries producing inputs for agriculture and agro-based industries. Private sector investments in agriculture will also be encouraged more particularly in areas like agricultural research, human resource development, post-harvest management and marketing. Rural electrification will be given a high priority as the prime mover for agricultural development. The quality and availability of electricity supply will be improved and the demand of the agriculture sector will be met adequately in a reliable and cost effective manner. The use of new and renewable sources of energy for irrigation and other agricultural purposes will also be encouraged.

Bridging the gap between irrigation potential created and utilized, completion of all on-going projects, restoration and modernization of irrigation infrastructure including drainage, evolving and implementing an integrated plan of augmentation and management of national water resources will receive special attention for augmenting the availability and use of irrigation water.

\section{WOMEN IN AGRICULTURAL DEVELOPMENT}

The Women in Agricultural Development Directorate (WIAD), is one of the seven Technical Directorates of the Ministry of Food and Agriculture (MOFA).

\section{Dr Mrs Mary Opoku Asiama - Director, WIAD} Vision \& Mission

* A highly professional and competent Public Institution that supports livelihood and well being of especially women in the agricultural sector.

* To develop effective policies and programs that promotes delivery of improved technologies and information on agricultural production and post production in an environmentally sustainable manner.

\section{Functions}

$>$ Improved nutrition interventions: biofortification, food fortification, food enrichment, nutrition education in relation to food production, post production and food consumption.

$>$ Value addition to agricultural produce: food processing and preservation

$>$ Food safety along the agricultural value chain (eg safe production and handling of exotic vegetables, cottage level processing, etc)

$>$ Resource management (farm, home, processing site)

$>$ Gender mainstreaming of all agricultural policies, programs and projects

\section{NEW AGRICULTURE POLICY}

Agriculture is a way of life, a tradition, which, for centuries, has shaped the thought, the outlook, the culture and the economic life of the people of India. Agriculture, therefore, is and will continue to be central to all strategies for planned socio-economic development of the country. Rapid growth of agriculture is essential not only to achieve self-reliance at national level but also for household food security and to bring about equity in distribution of income and wealth resulting in rapid reduction in poverty levels. Indian agriculture has, since Independence, made rapid strides. In taking the annual food grains production from 51 million tonnes in early fifties to 206 million tonnes at the turn of the century, it has contributed significantly in achieving self-sufficiency in food and in avoiding food shortages.

Over 200 million Indian farmers and farm workers have been the backbone of India's agriculture. Despite having achieved national food security the well being of the farming community continues to be a matter of grave concern for planners and policy makers. The establishment of an agrarian economy which ensures food and nutrition to India's billion people, raw materials for its expanding industrial base and surpluses for exports, and a fair and equitable reward system for the farming community for the services they provide to the society, will be the mainstay of reforms in the agriculture sector.

The National Policy on Agriculture seeks to actualize the vast untapped growth potential of Indian agriculture, 
strengthen rural infrastructure to support faster agricultural development, promote value addition, accelerate the growth of agro business, create employment in rural areas, secure a fair standard of living for the farmers and agricultural workers and their families, discourage migration to urban areas and face the challenges arising out of economic liberalization and globalisation. Over the next two decades, it aims to attain: The Salient Features of the new Agricultural Policy are

* Over 4 per cent annual growth rate aimed over next two decades.

* Greater private sector participation through contract farming.

* Price protection for farmers.

* National agricultural insurance scheme to be launched.

* Dismantling of restrictions on movement of agricultural commodities throughout the country.

* Rational utilization of country's water resources for optimum use of irrigation potential.

* High priority to development of animal husbandry, poultry, dairy and aquaculture.

* Capital inflow and assured markets for crop production.

* Exemption from payment of capital gains tax on compulsory acquisition of agricultural land.

* Minimise fluctuations in commodity prices.

* Continuous monitoring of international prices.

* Plant varieties to be protected through a legislation.

* Adequate and timely supply of quality inputs to farmers.

* High priority to rural electrification.

* Setting up of agro-processing units and creation of off-farm employment in rural areas.

\section{CONCLUSION}

Importance of agriculture sector in Indian economy cannot be undermined. The sector along with its significant achievements in form of Green, Blue and White revolution has developed certain stress points over a period. The human resource base for the agriculture sector is weak and there is a growing gap between scientific know-how and field levels do-how. This knowledge deficit should be overcome speedily in order to enhance the productivity and profitability of the small farms. The ODL can play a pro-active role in successful implementation of the Skill Development Mission through interventions like: development of competency based curricula and multi-media training modules, designing and implementing the testing and certification mechanism and development of qualification framework. It can also facilitate in creating a value added ICT enabled system. Implementation of skill development mission in area of agriculture through ODL shall ensure wider participation in equity mode.

"Give a man a fish and you feed him for a day. Teach a man to fish and you feed him for a lifetime." -Chinese Proverb.

\section{REFERENCES}

[1] www.icar.org

[2] www.planningcommission.nic.in

[3] Business Standard, New Delhi, Editorial: Farmers vs. peons August 20, 2008

[4] India Today ( June 11,2007) : Agriculture: Grain Drain: 38

[5] National Development Council Meeting. (2005). 51 st Meeting of the NDC held on $27^{\text {th }}$ June 2005 at Vigyan Bhawan, New Delhi.

[6] Swaminathan, M.S. (2005). Sustainable Farming. The Hindu Survey of Indian Agriculture 2005(Annual). Chennai.

[7] Human resource development for agricultural sector in India, D. Rama Rao, Principal Scientist National Academy of Agricultural Research Management, Rajendranagar, Hyderabad - 500 030. India.

[8] Human resource development for agricultural sector in India, K Vizayakumar Professor, Department of Industrial Engineering and Management, Indian Institute of Technology, KHARAGPUR. India 721302 . 